\title{
Exposure as Collected Supplemental Qualifiers Dataset
}

National Cancer Institute

\section{Source}

National Cancer Institute. Exposure as Collected Supplemental Qualifiers Dataset. NCI

Thesaurus. Code C147208.

A dataset containing supplemental information, specifically non-standard variables, to parent records in the exposure as collected domain. 